\title{
The Validity of Grant-Back Clauses in Patent Licensing Agreements
}

A party who obtains a patent (a patentee) is in effect granted monopoly rights over the patented invention for a period of seventeen years. ${ }^{1}$ Since the value of this exclusive right may be undermined by the development of improvements to or substitutes for the patented invention, a patentee has a clear interest in obtaining control over technological improvements to his patent (the original patent) developed by other parties.

Contractual "grant-backs" are frequently employed to obtain control over such new developments (improvement patents). The patentee (licensor) requires the potential licensee to agree to grant back to the patentee rights to improvement patents developed by the licensee that relate to the original patent as partial consideration for the license rights. ${ }^{2}$ The validity of grant-backs has been challenged under two theories. First, the grant-back arrangement has been challenged on the ground that it violates the public policy underlying the federal patent laws by enabling the patentee to expand the scope of his lawful patent monopoly. ${ }^{3}$ Although the courts have generally rejected this contention, recent developments cast doubt on the firmness of such holdings. ${ }^{4}$ Second, individual

1 The patent laws of the United States, 35 U.S.C. $\$ \S 1-293$ (1970) are intended to "promote the Progress of Science and useful Arts, by securing for limited Times to Authors and Inventors the exclusive Right to their respective Writings and Discoveries . . . U.S. Const. art. I, $\$ 8$.

35 U.S.C. $\$ 154(1970)$ states:

Every patent shall contain a short title of the invention and a grant to the patentee, his heirs or assigns, for the term of seventeen years, subject to the payment of issue fees as provided for in this title, of the right to exclude others from making, using, or selling the invention throughout the United States, referring to the specification for the particulars thereof.

2 The actual bundle of rights conveyed by a grant-back may vary widely in scope. See text and notes $6-8$ infra.

${ }^{3}$ Stokes \& Smith Co. v. Transparent-Wrap Mach. Corp., 156 F.2d 198 (2d Cir. 1946), rev'd 329 U.S. 637 (1947). See text and notes at notes 10-21 infra.

- It has been argued that Brullote v. Thys Co., 379 U.S. 29 (1964), which extended the applicability of the rationale underlying this policy argument to a new fact setting, undermines the refusal of the courts to invalidate grant-backs per se. See W. Bowman, Patent \& Antitrust Law 232 (1973); Chevigny, The Validity of Grant-back Agreements Under the Antitrust Laws, 34 Ford. L. Rev. 569, 570 (1966) [hereinafter cited as the FordHAM ARTicle]. Also, the Justice Department has expressed the belief that certain grant-backs should be invalid per se. See text and notes at notes 39-45 infra. 
grant-backs have also been challenged as violative of the antitrust laws. ${ }^{5}$

This comment first discusses the possible types of grant-back arrangements and suggests reasons for their popularity. The judicial response to the question of grant-back validity is then examined. Finally, economic analysis is applied to the various types of grantbacks. The comment argues that grant-backs should be presumptively permissible because economic analysis strongly supports the proposition that grant-backs do not violate the public policy embodied in the patent laws. Individual grant-backs should not, however, be immunized from antitrust scrutiny.

\section{The Background of Grant-Backs}

\section{A. A General Description}

Since grant-backs are created by contract, they may vary both in the nature of the rights granted back and in the scope of future developments covered by the clause. When the original patentee acquires full patent rights to the improvement patents, the grantback is termed an "assignment-back." When the licensee of the original patent retains the patent rights to the improvement patents and the original patentee is given only the right to use rather than to control the improvement patents, the grant-back is called a "license-back." Of course, a grant-back clause can contain characteristics common to both the assignment-back and license-back.

Grant-back clauses may vary widely in defining the types of improvement patents to be granted back to the licensor; the scope of grant-backs can be generally defined as either "broad" or "narrow." Broad clauses require the licensee to grant-back all improvement patents relating to the original patent. ${ }^{6}$ Narrow clauses cover only those inventions or acquisitions that relate directly to the original patent. ${ }^{7}$ Although the distinction between broad and narrow

5 The Justice Department has brought actions under the Sherman Antitrust Act, 15 U.S.C. $\$ \S 1-7$ (1970); see text and notes at notes 24-31 infra.

- See, e.g., Zajicek v. Koolvent Metal Awning Corp. of America, 283 F.2d 127 (9th Cir. 1960), cert. denied, 365 U.S. 859 (1961), in which the agreement contained the following clause:

In the event Licensee or any of its employees shall make or acquire any invention or improvement relating to the licensed inventions, then the Licensee shall disclose and communicate such invention or improvement to Koolvent [Licensor] and shall aid and assist in acquiring patent protection thereof . . . . Id., at 131 n.3.

7 See, e.g., Old Dominion Box Co. v. Continental Can Co., 273 F. Supp. 550 (S.D.N.Y. 1967), aff'd, 393 F.2d 321 (2d Cir. 1968), in which the license called for grant-backs of any "improvements," and defined improvements as follows: 
clauses is not always clear in practice, a sharp theoretical line can be drawn. Narrow clauses will be defined as those clauses limited to improvements that relate so closely to the original patent that their use would constitute an infringement of the original patent. ${ }^{8}$

There are, therefore, four general categories of grant-backs with which this comment is concerned: the broad scope assignmentback, the broad scope license-back, the narrow scope assignmentback, and the narrow scope license-back. Each type of grant-back may raise distinguishable questions of validity.

\section{B. The Purpose of Grant-Backs}

There are two principal reasons for the inclusion of grant-back clauses in patent licensing agreements. First, licensors who produce under their own patents or consider doing so may insist on a grantback clause to assure future access to improvement patents developed by their licensees. If the licensee develops a patentable improvement to the licensor's patent and becomes the sole patentee under that improvement patent, he alone will be able to exploit the improved technology while the licensor may be left with an obsolete and useless process. A grant-back provision in the licensing agreement protects the licensor from this result. A patentee may prefer not to sell rights to his patent without the assurance that he will not be forced to compete with his licensees at a disadvantage.

Second, the parties may negotiate a grant-back arrangement to ensure unified control over an entire process. Just as a large undeveloped tract of urban land is more valuable than the sum of its constituent parts, an entire patented process is more valuable than the aggregate value of the component patents. The parties may, therefore, use grant-backs to maximize the overall efficiency of their relationship. ${ }^{9}$

[A]ny modification of the Cartons or Carton applying machines . . . or . . . any modification of inventions which are within the scope of the Patent Rights.

Id., at 569.

" Often, the question presented is whether the grant-back was drafted in sufficiently broad language to cover the improvement patent at issue. See, e.g., Binks Mfg. Co. v. Ransburg Electro-Coating Corp., 281 F.2d 252 (7th Cir. 1960), cert. granted, 364 U.S. 926 (1960), petition for cert. dismissed as not warranted on record, 366 U.S. 211 (1961). Patent infringement is defined as "the unauthorized making, using, or selling for practical use, or for profit, of an invention covered by a valid claim of a patent during the life of the patent." BLACK's Law Dictionary 912 (4th ed. 1951) (citing cases).

- Theoretically, the parties will reach such an agreement if: (1) they are free to bargain for the compensation of the party who will not receive control of both patents; (2) they can be reasonably certain of the legal effect of their bargain; and (3) the cost of such bargaining does not exceed the savings generated by increased efficiency. See generally Coase, The 


\section{Judicial Treatment of Grant-Back Arrangements}

\section{A. The Transwrap Case}

The question of the permissibility of the grant-back arrangement has been extensively discussed only in Transparent-Wrap Mach. Corp. v. Stokes \& Smith Co., ${ }^{10}$ commonly known as Transwrap. The Transwrap Corporation held a series of patents on a machine that made, filled, and sealed cellophane packages for candy, nuts, and the like. Transwrap granted the Stokes \& Smith Co. an exclusive North American license to the patented process on the condition that it assign back to Transwrap the rights to any improvement patents that it might develop. ${ }^{11}$ Stokes \& Smith thereafter developed patents within the scope of the clause but refused to grant them back to Transwrap. After negotiations failed to resolve the ensuing dispute, Stokes \& Smith brought a declaratory action for intrepretation of the contract. Transwrap counterclaimed, praying for assignment of the disputed patents. Stokes \& Smith defended the counter-claim on the ground that the grantback clauses were unenforceable per se.

Judge Learned Hand, writing for the majority of a Second Circuit panel, found assignment-backs to be per se unlawful and unenforceable. ${ }^{12}$ In reaching this conclusion, Judge Hand analogized assignment-backs to impermissible patent tie-ins. In a tie-in arrangement, the patentee requires the potential licensee to purchase an unpatented product in order to acquire the desired license to the patented product. The Supreme Court had previously held that such an arrangement violated the federal public policy as embodied in the Constitution and the patent laws by enabling the patentee to extend its lawful monopoly beyond its original scope..$^{13}$

Judge Hand believed that assignment-backs, like tie-ins, had the effect of broadening the scope of the lawful patent monopoly. His reasoning assumed that there would be a period of time after the expiration of the original patent when the patentee-licensor

Problem of Social Cost, 3 J. LAw \& EcoN. 1 (1960). Unified ownership may also make it easier for potential licensees to purchase rights to the entire process; negotiation costs will be reduced if they have to bargain with only one licensor and the possibility that sale of the entire process will be blocked by the holder of the last patent in the series seeking a hold-out premium will be eliminated.

10329 U.S. 637 (1947), rev'g 156 F.2d 198 (2d Cir. 1946).

"The assignment-back covered any "improvement which is applicable to the Transwrap Packaging Machine and suitable for use in connection therewith . . . " 329 U.S. at $639 \mathrm{n}$. 1.

12156 F.2d 198 (1946).

${ }^{13}$ Morton Salt Co. v. G.S. Suppiger Co., 314 U.S. 488 (1941). 
alone would be able to exercise monopoly rights over the improved patented process, thereby extending the duration of its lawful monopoly. ${ }^{14}$ Although Judge Hand held assignment-backs to be invalid per se, he implied in dicta that license-backs were presumptively valid since the retention of the patent rights over the improvements by the licensee would prevent the patentee-licensor from extending the duration of its patent monopoly.15

The Supreme Court reversed the Second Circuit with Justice Douglas writing for a five man majority. ${ }^{16}$ Justice Douglas initially noted that the theory Judge Hand relied upon did not require a finding of violation of the antitrust laws. Rather, an arrangement would be invalidated per se under the tie-in theory if it expanded the patent monopoly and thus tended to restrain trade. Justice Douglas then observed that, since Congress had made all patents assignable, it should not matter if a patent is assigned in a licenseagreement rather than for some other consideration. Since Congress has explicitly sanctioned patent assignments, it would indeed be odd for the courts to invalidate the assignments on the ground that they violate the policy of the law which authorizes them.

Justice Douglas recognized that these propositions did not fully meet Judge Hand's arguments. He then observed that the analogy of grant-backs ${ }^{17}$ to tie-ins was weak. A tie-in arrangement, he noted, uses the patent rights to expand the monopoly power to nonpatented products. Grant-backs, on the other hand, involve "using one legalized monopoly to acquire another legalized monopoly." 18 The tendency towards restraint of trade created by grant-backs is therefore not violative of public policy but sanctioned by it. ${ }^{19}$

14 If the original patent was due to expire in 1953 then the improvement patent would necessarily expire at some later date, say 1957 . In this case, the patentee-licensor would have used his original patent monopoly to create a longer lasting monopoly.

is 156 F.2d 198, 202-03. The logic of his license-back conclusion is correct. Since licenseback agreements involve no transfer of monopoly rights, there can be no resultant monopoly expansion.

16 329 U.S. 637. Justices Black, Rutledge and Burton would have affirmed the decision below on the strength of Judge Hand's opinion. Justice Murphy believed the majority had unduly enlarged the scope of patent monopolies, 329 U.S. at 648 .

Certiorari had been granted because of the seeming conflict between Judge Hand's opinion and Allbright-Nell Co. v. Stanley Hiller Co., 72 F.2d 392 (7th Cir. 1934). The latter case upheld an assignment-back clause in an employment agreement. That case, however, did not address the question of whether assignment-backs were enforceable, but whether the agreement in fact contained such a clause, 72 F.2d at 394.

${ }_{17}$ Although Justice Douglas referred to the arrangement in question as a "license-back," the clause actually called for an assignment-back of rights. See text at notes 6-8 supra.

is 329 U.S. at 644.

19 Id., 642-45. 
Grant-backs were thus held not to be unenforceable per se as an impermissible patent abuse. Justice Douglas warned, however, that this holding did not immunize grant-backs from antitrust scrutiny. He noted that grant-backs might violate the antitrust laws if they constituted part of a larger, monopolistic scheme or if multiple grant-backs had a funnelling effect that resulted in unlawful market control. ${ }^{20}$

Transwrap was remanded for a determination of whether the antitrust laws had been violated. On remand, the Second Circuit held that the record did not support a finding that any antitrust law had been violated. ${ }^{21}$

\section{B. The Post-Transwrap Period}

The Supreme Court Transwrap opinion left certain questions concerning the validity of the grant-back arrangement unanswered. Although the Court held that grant-backs did not violate public policy per se, it did not indicate whether a specific grantback could violate the public policy underlying the patent laws. The logic of the tie-in cases-arrangements that expand the lawful patent monopoly and thus tend towards an unreasonable restraint of trade are invalid-would suggest not. Yet this conclusion is not indisputable. Justice Douglas' opinion also left identification of the circumstances in which grant-backs could be used to violate the antitrust laws unresolved. Justice Douglas evidently contemplated that future courts would scrutinize the effects that flowed from a given grant-back in order to make this determination.

Although the validity of grant-backs has been at issue in many cases since Transwrap, the law on the subject has not been refined or reexamined during this period. Largely because of the context in which these cases have arisen, the courts have, for the most part, been content to reiterate the proposition that grant-backs are not unenforceable per se and have failed to scrutinize the validity issue with great care or effort.

One context in which these cases have arisen is where an alleged patent infringer who is sued by a patentee defends the suit by alleging that the patent is invalid due to patent abuse partially

${ }^{20}$ Id., at 647 . See note 26 infra.

21 Stokes \& Smith Co. v. Transparent-Wrap Mach. Corp., 161 F.2d 565 (2d Cir. 1947). On remand, the Second Circuit had only the agreement itself in the record. Judge Hand wrote for the unanimous court that the double monopoly created by the agreement did not violate the antitrust laws because the market extension was not equivalent to an unreasonable restraint of trade. 
stemming from the existence of a grant-back clause. ${ }^{22}$ Yet the validity of the grant-back itself is rarely brought into sharp focus in these cases. The grant-backs are generally raised as a single piece of evidence of a broader patent abuse by the patentee. Courts typically dispose of the grant-back question summarily, citing Transwrap for the principle that grant-backs are permissible in the absence of an independent violation of the antitrust laws. ${ }^{23}$

A similar situation arises in grant-back cases prosecuted by the Justice Department. ${ }^{24}$ Although the Justice Department has been reasonably successful in challenging grant-backs under the antitrust laws, ${ }^{25}$ the successful challenges have been directed against pooling arrangements, in which the grant-back clause was but one of several devices used to unreasonably restrain trade..$^{28}$ The Department has never prevailed in a case involving grant-backs alone. The profusion of issues in these cases has obscured the grant-back issue, that question often being treated briefly and rather mechanically. ${ }^{27}$

22 See, e.g., Barr Rubber Products Co. v. Sun Rubber Co., 277 F. Supp. 484 (S.D.N.Y. 1967); Modern Art Printing Co. v. Skeels, 123 F. Supp. 426 (D.N.J. 1954).

${ }_{23}$ See Barr Rubber Products Co. v. Sun Rubber Co., 277 F. Supp. 484 (S.D.N.Y. 1967); Old Dominion Box Co. v. Continental Can Co., 273 F. Supp. 550 (S.D.N.Y. 1967); Swofford v. B \& W Inc., 251 F. Supp. 811 (S.D. Tex. 1966); Well Surveys, Inc. v. McCullough Tool Co., 199 F. Supp. 374 (N.D. Okla. 1961); International Nickel Co. v. Ford Motor Co., 166 F. Supp. 551 (S.D.N.Y. 1958); Modern Art Printing Co. v. Skeels, 123 F. Supp. 426 (D.N.J. 1954).

24 See, e.g., Imperial Chemical Indus., Ltd. v. United States, 105 F. Supp. 215 (S.D.N.Y. 1952); United States v. Besser Mfg. Co., 96 F. Supp. 304 (E.D. Mich. 1951).

${ }^{25}$ The antitrust laws were held to be violated in the following cases by arrangements that included grant-backs: United States v. Switzer Bros., Inc., 1953 Trade Cas. 967,598 (N.D. Cal. 1953) (grant-back clause one of several items enjoined by consent decree); United States v. Imperial Chemical Indus., Ltd., 105 F. Supp. 215 (S.D.N.Y. 1952); United States v. Besser Mfg. Co., 96 F. Supp. 304 (E.D. Mich. 1951); United States v. Aluminum Co. of America, 91 F. Supp. 333 (S.D.N.Y. 1950); United States v. General Electric Co., 82 F. Supp. 753 (D.N.J. 1949) (lamps); and United States v. General Electric Co., 80 F. Supp. 989 (S.D.N.Y. 1948) (carbology). Violations were not found in: United States v. Huck Mfg. Co., 227 F. Supp. 791 (E.D. Mich. 1964); and United States v. E.I. du Pont de Nemours \& Co., 118 F. Supp. 41 (D. Del. 1953).

${ }^{26}$ See, e.g., United States v. General Electric Co., 80 F. Supp. 989 (S.D.N.Y. 1948) (carbology). Both sections 1 and 2 of the Sherman Act, 15 U.S.C. $\S \S 1,2$ (1970) were held to be violated.

The third section of Justice Douglas' opinion in Transwrap, 393 U.S. at 647, indicated that grant-backs could be employed in a way that violates the antitrust laws. Justice Douglas cited Hartford-Empire Co. v. United States, 323 U.S. 386, reargued, 324 U.S. 570 (1945) as an illustrative example. The defendant there had acquired a pool of over 600 patents in one industry, partially through the use of grant-backs. The discussion did not concern the issue of the validity of the grant-back arrangement per se, but the use to which specific grant-backs were put.

${ }_{27}^{27}$ See, e.g., United States v. General Electric Co., 82 F. Supp. 753, 815-16 (D.N.J. 1949) (lamps). 
Discussion of the grant-back issue has been more prominent, however, in several cases. For example, in United States v. General Electric Co. ${ }^{28}$ the court found violations of Sections 1 and 2 of the Sherman Act $^{29}$ when the licensor, who was in the dominant market position and owned, through patent-pooling activities, the dominant patents, was able to funnel the effects of grant-backs made with numerous licensees into a position of unreasonable market control. In a similar case, Kobe, Inc. v. Dempsey Pump Co. ${ }^{30}$ the court noted that, while grant-backs are not impermissible per se, they may, like every other contract, violate Sections 1 and 2 of the Sherman Act when made to secure and perpetuate a monopoly in restraint of trade. ${ }^{31} \mathrm{It}$ is significant that the courts did not find per se violations in these cases but rather scrutinized the impact of the individual grant-backs on an actual market.

Finally, the issue arises when licensees sue to have the grantback invalidated or the licensor sues for enforcement of the grantback. ${ }^{32}$ There are two principal reasons why these cases as well have not contained careful discussion of the validity issue. Some cases are similar to infringement cases, with the grant-back issue being peripheral. ${ }^{33}$ In other cases, the courts have been able to avoid dealing with the validity issue by construing the grant-back clause narrowly and finding the alleged improvement to be outside its scope. ${ }^{34}$

The case law since Transwrap has therefore done little more than reiterate that grant-backs are not invalid per se but may violate the antitrust laws under certain circumstances. Recent developments, however, cast doubt on the continuing vitality of Transwrap. The first such development came in 1964 when the Supreme Court resurrected the logic of the tie-in case and relied upon its applicability in Brulotte $v$. Thys Co. ${ }^{35}$ The Court held that provisions of a patent licensing agreement that provided for royalty payments for the use of certain patents could not be enforced after the expiration date of the last patent in the series. Justice Douglas, who wrote for

2882 F. Supp. 753, 815-16 (D.N.J. 1949) (lamps).

29 See note 5 supra.

so 198 F.2d 416 (10th Cir. 1952), cert. denied, 344 U.S. 837 (1952).

31 See also, United States v. Aluminum Co. of America, 91 F. Supp. 333 (S.D.N.Y. 1950); and United States v. General Electric Co., 80 F. Supp. 989 (S.D.N.Y. 1948).

${ }^{32}$ See, e.g., Deering Millinken Research Corp. v. Leesona Corp., 201 F. Supp. 776 (E.D.N.Y. 1962), aff'd 315 F.2d 475 (2d Cir. 1963).

${ }^{33}$ See, e.g., Zajicek v. Koolvent Metal Awning Corp. of America, 283 F.2d 127 (9th Cir. 1960), cert. denied, 365 U.S. 859 (1961).

${ }^{31}$ E.g., Deering-Milliken Research Corp. v. Leesona Corp., 201 F. Supp. 776 (E.D.N.Y. 1962), aff'd 315 F.2d 475 (2d Cir. 1963).

ss 379 U.S. 29 (1964). 
the slim majority in Transwrap, wrote for eight justices in Brulotte:

A patent empowers the owner to exact royalties as high as he can negotiate with the leverage of that monopoly. But to use that leverage to project those royalty payments beyond the life of the patent is analogous to an effort to enlarge the monopoly of the patent by tieing the sale or use of the patented article to the purchase or use of unpatented ones..$^{36}$

Such arrangements were held to be unenforceable per se. Assuming the correctness of Brulotte, ${ }^{37}$ it has been suggested that this extension of the tie-in logic undermines the Transwrap holding. ${ }^{38}$

More importantly, there have been indications during the past decade that the Justice Department believes that the decision in Transwrap should be modified significantly. ${ }^{39}$ The Justice Department's major objection to grant-backs appears to be the belief that such provisions stifle the licensee's innovation incentive..$^{40}$ Since the effect of the grant-back on incentive is the major concern, the Justice Department has, as an element of its antitrust enforcement policy, considered assignment-backs and exclusive license-backs to be per se antitrust violations. ${ }^{41}$ One consent decree has been negotiated on the basis of the Justice Department's disapproval.42

sh Id. at 33.

${ }^{37}$ The logic of the tie-in cases may well be unsound. See text and notes at notes $52-54$ infra.

${ }^{37}$ See sources cited at note 4 supra.

38 The Justice Department's displeasure with Transwrap has been manifested by public statements of several senior members of the Department with enforcement responsibility in this area of law. In 1965, Donald F. Turner, then Assistant Attorney General in charge of the Antitrust Division, declared that it was the policy of the Department to consider assignmentbacks and exclusive license-backs to be per se antitrust violations. Turner also indicated that the Department would "eventually seek" to have the Transwrap decision overruled on this point. 29 A.B.A. AnTrtrust L.J. 187, 188, 192 (1965). In 1969, Richard W. McLaren, Assistant Attorney General in the Antitrust Division, proposed a standard for examining the legality of grant-backs more stringent than the standard announced in Transwrap. Again, McLaren's standard is aimed primarily at those grant-backs which are perceived to extend substantially the patentee's lawful monopoly. Dunne, Anti-Competitive Considerations of Patent Accumulation by License Grant-Back Provisions, 57 J. PAT. OFF. Soc'y 124, 132 n.25 (1975). In 1971, Richard H. Stern, Chief of the Antitrust Patent Unit, expressed the strong belief that exclusive grant-backs stifle the licensee's incentive to innovate. 47 BNA PAT., T.M. \& CPYRT. J., Oct. 7, 1971. The common theme which ties these public statements together is a dissatisfaction with the refusal of the Court in Transwrap to subject grant-backs to a higher standard of scrutiny than an ordinary contractual provision. Although the spokesmen have not agreed on what standard should be used, the fact of dissatisfaction with the existing standard is clear.

11' Stern, supra note 39.

"Turner, supra note 39.

12 United States v. Wisconsin Alumni Research Foundation, 1970 Trade Cas. $\uparrow 73,015$ (W.D. Wis. 1970). The decree invalidated grant-back provisions but allowed agreements 
Although this consent decree is not an authoritative precedent, it is quite possible that the use of grant-backs has declined in recent years in deference to the Justice Department's position..$^{43}$ Thus, given the Justice Department's long standing and publicly made objections to the rationale and decision in Transwrap, and the practical effects of an inhibiting nature which have possibly flowed from this stance, it is quite possible that the Justice Department will directly challenge the Transwrap case either to establish its desired position on the issue of grant-backs ${ }^{44}$ or merely to clarify the law in this area and lend a greater degree of certainty to this significant aspect of patent law..$^{45}$

The remainder of this comment will apply economic analysis to the major arguments that have been marshalled against grantbacks to determine the extent to which grant-backs are economically harmful; such an analysis is necessary in order to make a judgment about the correctness and present utility of the Transwrap decision.

\section{An Analysis of the Economic Impact of Grant-Backs}

Two major economic arguments were directed against grantbacks in Transwrap: (1) grant-backs enable the patentee-licensor to expand the scope of his lawfully granted patent monopoly; ${ }^{48}(2)$ grant-backs discourage innovation. ${ }^{47}$ This section will analyze the

requiring licensees to grant other licensees non-exclusive license-backs. The consent decree does not have great precedential weight for two reasons. First, the facts of the case were not disclosed. It is therefore impossible to ascertain how abusive the improper practices were. Second, the rationale of the decision was not explicated, the opinion merely noting the existence of jurisdiction under the Sherman Act.

${ }^{13}$ Dunne, supra note 39, at 132 (1975).

"It is not clear what the precise nature of the Justice Department's challenge would be, particularly since agency policies change over time with some rapidity. It is not crucial to this analysis to know the precise Justice Department position; the significant point is that the past dissatisfaction with the Transwrap rule points to the possibility of a direct challenge of some nature.

45 Given that the Justice Department has publicly declared, through its spokesmen, that it is not in full agreement with the Transwrap decision, there may be an independent need for a challenge to Transwrap in order to settle the question definitively. The need for certainty in this area of law could be fulfilled by a Justice Department challenge to Transwrap. When agency practice and Supreme Court precedent diverge as greatly as they do in this situation, it may indeed be in the public interest and in the interest of the agency to adjudicate the matter promptly. This comment seeks to provide additional analytical evidence in support of Transwrap if such a challenge materializes.

${ }^{16}$ See, e.g., Stokes \& Smith Co. v. Transparent-Wrap Mach. Corp., 156 F.2d 198, 202 (2d Cir. 1946).

tT See, e.g., Transparent-Wrap Mach. Corp. v. Stokes \& Smith Co., 329 U.S. 637 (1947). See also R. Nordhaus \& E. Jurow, Patent Antitrust Law 226-38 (2d ed. 1972); and Fordham ARTICLE, supra note 4. 
strength of these arguments from an economic perspective.

\section{A. The Patent Monopoly Abuse Theory}

As noted above, ${ }^{48}$ Judge Hand concluded that the reasoning of the tie-in cases was dispositive in the grant-back case. The Supreme Court did not quarrel directly with Judge Hand's assessment that a grant-back clause might enable the patentee-licensor to expand the scope of his patent monopoly, but rather held that reliance on the expansion theory was misplaced because the patent laws sanctioned the acquisition of the second monopoly. ${ }^{49}$ Although Brulotte ${ }^{50}$ casts doubt on the firmness of the Court's refusal to apply the tiein rationale,,$^{51}$ modern economic theory suggests that this result is sound for reasons in addition to those cited by the Court in Transwrap.

Commentators have criticized the so-called "leverage theory" that tying arrangements expand the scope of the patentee's lawful monopoly. ${ }^{52}$ It has been persuasively argued that even though the patent "tyer" can exert monopoly power over the unpatented tie-in product, this ability will not enable him to increase his monopoly profits. By hypothesis, the patentee has established the selling price for the license right to its patent that will maximize its monopoly profit. If the patentee charges a price above competitive levels for the tied-in product, the additional increment may be viewed by potential licensees as a surcharge for the patent license rights. Sales of license rights should drop because they are now priced higher..$^{53}$ A constant level of sales despite a rise in price would indicate that the license rights previously had been priced beneath the optimal monopoly price. Thus, although a tie-in may prod a patentee into extracting a larger portion of its possible monopoly profit, the possible monopoly profit itself remains unaffected.

Since the rationale of the tie-in cases-that the arrangement expands the patent monopoly-is unsound, the Supreme Court was correct in refusing to invalidate the grant-back arrangement on the

4 See text at notes 12-15 supra.

"See text at notes 16-19 supra.

so Brulotte is, of course, arguably distinguishable from the case of grant-backs. The expansion of the patent monopoly in Brulotte stemmed from the exaction of royalty payments beyond the expiration date of the patent. The expansion in grant-back cases, on the other hand, results from the acquisition of a second, but legally sanctioned, patent.

${ }^{31}$ See sources cited at note 4 supra.

52 See W. Bowman, Patent and Antitrust Law 117-19 (1973); and R. Posner, Economic ANALYSIS OF LAW 125-26 (1973) [hereinafter cited as POSNER].

${ }^{33}$ POSNER, at $125-26$. 
strength of this theory. There can be no justification for extending unsound doctrine at all, let alone to an arguably distinguishable case. The critical distinction is that, in the tie-in cases, potential customers are forced to buy the "tied" product in order to purchase the desired product, whereas grant-backs do not require the licensee to purchase an additional product or pay an additional premium. The licensee agrees only to transfer or share certain patent rights that might never come into existence.

Furthermore, the patentee-licensor can no more increase its monopoly profits through a grant-back clause alone than a patentee-tier ${ }^{54}$ can through the tying arrangement alone. In order to persuade potential licensees to agree to a grant-back clause in the licensing agreement, it can be reasonably assumed that the licensor will make some offsetting concession..$^{55}$

The conclusion that grant-backs do not expand patent monopoly profits is not dependent upon the type of grant-back involved. Theoretically, a broad scope assignment-back transfers the greatest bundle of rights to the patentee-licensor. A potential licensee may recognize this fact and view the potential increment as an additional charge for the desired original patent rights. If the patenteelicensor had been selling license rights to the original patent at the optimal monopoly level, it would have to reduce that price in relation to the value of the transfer rights to keep its profit constant. The analysis is similar if the grant-back calls for a narrow scope assignment-back. Since this arrangement involves the minimal possible transfer of rights, it would lead to the smallest reduction from the selling price of the license rights alone. It follows from this analysis that any grant-back transfering an intermediate amount of rights would also not expand the patentee-licensor's profits.

The thrust of Brulotte, however, unlike the tie-in cases, was not directed to the issue of whether the given arrangement had broadened the scope of the patent monopoly. In Brulotte an arrangement

st Tie-in arrangements may be invalid even when they do not involve a patented product; the legal theory in such a case does not, quite obviously, rest on a violation of the patent law policies. These cases come under the Sherman Act and require findings that (1) there are two products involved; (2) the seller has sufficient market power to affect competition adversely through the arrangement; and (3) not an insubstantial amount of commerce is foreclosed in the market of the tied-in service or product. See Wang, The Unbundling of Higher Education, 1975 DUKE L.J. 53, 69-71 (1975).

${ }_{55}$ The Transwrap majority demonstrated implicit awareness that either the market would not always work properly or could be manipulated to reach an unusual result when it wrote that grant-backs were not immune from antitrust scrutiny, 329 U.S. 637, 647 (1947). See Fordham ARTiCLE, supra note 4, for a discussion of the antitrust implications of the cases that the author assumes were left open by Transwrap. 
was invalidated that effectively extended the duration of the original patent monopoly beyond its designated termination date. This insight, that assignment-backs extended the duration of the patent monopoly, was central to Judge Hand's conclusion that assignmentbacks are invalid per se and was not directly challenged by Justice Douglas in overruling the decision below. Justice Douglas' answer to Judge Hand was that, since the patent laws sanctioned the acquisition of the second patent as well as the device by which it was obtained, it did not necessarily matter that the original monopoly had been extended. ${ }^{56}$

Brulotte, therefore, is distinguishable from the grant-back case. The extension of the patent monopoly in Brulotte stemmed from the exaction of royalty payments beyond the expiration date of the patent, an exaction, unlike that in the grant-back case, that is nowhere sanctioned by the law. The logic of the patent system suggests that Brulotte should not be viewed as undermining Transwrap.

Analysis suggests, therefore, that grant-backs should not be invalidated per se as being violative of the patent law policies. Grant-backs do not themselves expand the scope of the lawful patent monopoly. Although assignment-backs may result in an extension of the effective duration of the original patent monopoly, this extension is irrelevant because it is sanctioned by the patent laws. It follows that grant-backs should not be invalidated per se because they do not necessarily produce harmful economic results. Since harmful effects will occur only in specific instances, judicial scrutiny of grant-backs should be confined to an examination under the antitrust laws of the impact that a specific grant-back clause has had upon an actual market.

\section{B. Discouragement of Innovation}

It has been argued that even if grant-backs are not unenforceable under the tie-in rationale, they violate another major public policy. It is argued that grant-backs thwart the purpose of the patent laws to promote scientific progress because a licensee has little incentive to innovate when forced to turn over the fruits of his genius. 57

36 Hand's argument only goes to assignment-backs. In license-backs, by definition, the patent monopoly of the patentee-licensor cannot be extended. The patentee-licensor retains only access to rather than control over improvement patents. It would have the power to restrict licensing to the original patent only for the period allotted by the patent laws. The scope of the license-back would have no bearing on this conclusion.

${ }_{77}$ Transparent-Wrap Mach. Corp. v. Stokes \& Smith Co., 329 U.S. 637, 646 (1947). 
Justice Douglas rejected this contention in Transwrap without substantial supporting argument. Although he observed that the patentee retained free rights to the assigned-back patent and thus did have an innovation incentive, the basis of his argument was that incentive impairment was too conjectural to appraise.$^{58}$ Economic analysis suggests that Justice Douglas' conclusion was correct.

Economists disagree on the relationship between patent innovation and apparent incentives. ${ }^{59}$ The case of grant-backs is complex and requires balancing factors since grant-backs have some effects that seem to discourage innovation and others that appear to be encouragements. Although these factors can not be balanced precisely, a clear showing of discouragement would be required to justify invalidating the grant-back per se on the theory that they necessarily frustrate the purpose of the patent laws.

Grant-back clauses may not always affect normal innovation incentives. The parties to grant-back agreements often may not contemplate that the licensee will actively engage in improvement research. Grant-backs thus may be designed to assure the licensor's access to inadvertently discovered improvements. Innovation would not be inhibited by grant-backs in these circumstances. This conclusion would follow whether, at one extreme, the grant-back calls for a full assignment-back of all patent rights, or merely a royaltyfree license-back of rights at the other. In all cases the licensee loses some potential benefit: if the arrangement provides for a full grantback, the licensee will lose potential royalties, as well as the monopoly control that he might otherwise have had; if the contract calls for a free license-back, the licensee will lose at least the royalties that the patentee-licensor would have otherwise paid; finally, if the license contract permits the original patentee-licensor to sub-license improvement patents granted back, then the licensee and the licensor may become competitors in seeking new license contracts. Yet the magnitude of the potential loss to the licensee would not affect innovation incentive in these circumstances since, by definition, improvement discovery is to be largely inadvertent.

Furthermore, to the extent the parties contemplate the likelihood of active research by the licensee or the licensor fears that the licensee will conceal any improvements, the licensor has an interest

ss Id.

${ }^{59}$ There have been numerous evaluations of the relationship between innovation and patent incentives. Cf. Arrow, Economic Welfare and the Allocation of Resources for Invention, in The Rate and Direction of Inventive Activity: Economic and Social Factors 609 (National Bureau Committee for Economic Research ed. 1962); and F. KNIGHT, RisK, UnCERTAINTY ANd Profit (8th ed. 1957). 
in ensuring that the clause will not dampen the licensee's incentives. This insight explains why many assignment-back clauses provide for the licensee to retain free rights to the transferred patent. ${ }^{60}$ Since the licensee retains the actual improvement patent under the license-back arrangement, there will be little danger of concealing improvements or failing to do research.

Even if it is assumed that grant-backs inhibit licensee incentive somewhat, a countervailing factor is that grant-backs may contribute to overall innovation production. Innovation by the patenteelicensor might well be inhibited if it could not insure against the early obsolesence of its patents. In this sense grant-backs may encourage original inventions. ${ }^{61}$

Finally, it would seem likely that a firm with a record of granting back valuable improvement inventions would be able to translate such performance into more favorable license terms, thus preserving some of the innovation incentive it might lose through other factors.

It has not been be persuasively argued that grant-backs inhibit innovation incentive and thereby undermine the policy of the patent laws to promote invention..$^{62}$ In the many cases where the clause assures the licensor's access to unanticipated improvements, it is likely that the licensee's incentives will be unaffected. Furthermore, where the parties have reason to anticipate incentive reductions, they can easily avoid the problem themselves by permitting the licensee free use of the improvements. Finally, the collateral benefits that flow from grant-backs could well offset any incentive inhi-

6 See, e.g., Zajicek v. Koolvent Metal Awning Corp. of America, 283 F.2d 127 (9th Cir. 1960), cert. denied, 365 U.S. 859 (1961); United States v. General Electric Co., 80 F. Supp. 989 (S.DN.Y. 1948) (carbology).

61 A related point is that grant-backs may encourage wide distributions of patent rights. A patentee assured of access to a newly relevant improvement patent will be more prone to sell license rights than one who is not. See Well Surveys, Inc. v. McCullough Tool Co., 199 F. Supp. 374 (N.D. Okla. 1961), aff'd, 343 F.2d 381 (10th Cir. 1965), cert. denied, 383 U.S. 933 (1966):

[T] he provision . . requiring licensees to grant back nonexclusive licenses under new inventions . . . did not have an anti-competitive effect, but tended to bring about a wider distribution of the use of new inventions.

343 F.2d at 395.

22 International Nickel Co. v. Ford Motor Co., 166 F. Supp. 551 (S.D.N.Y. 1958) demonstrates the merits of the view that grant-backs do not necessarily inhibit innovation. The court wrote:

I need devote little discussion to the allegation that the license-backs have stifled research. The Master found that considerable research has been conducted by licensees and that, any claim that absent the agreement, there would have been greater research is mere conjecture.

166 F. Supp. at 566. 
bitions that might otherwise result. A stronger showing would seem necessary to justify invalidating grant-backs per se on the theory that they necessarily inhibit incentive.

\section{Conclusion}

This comment has reassessed the Supreme Court's conclusion in Transwrap that grant-backs are not unlawful expansions of patent monopolies and violative of patent law policy in light of the doubts spawned by Brulotte and the displeasure expressed by the Justice Department. ${ }^{63}$ It has been argued elsewhere that only license-back arrangements should enjoy this judicial imprimatur since they adequately protect the patentee-licensor's access to new technology without producing the economic harm occasionally attributed to assignments. The analysis of this comment, however, suggests that neither license-backs nor assignment-backs necessarily either permit the patentee either to expand the scope of its monopoly or substantially inhibit licensee innovation incentive. Although broad scope assignment-backs may create a greater potential for manipulation of the market by the patentee, the clause itself does not necessarily produce results that are economically harmful. Grant-backs are not inherently harmful and should not be invalidated per se; they should, however, be scrutinized under the antitrust laws when part of a larger monopolistic scheme or device.

Richard Schmalbeck

${ }^{63}$ See Fordham ARTiCle, supra note 4, at 578; and McLaren supra note 39. 